\title{
The Arctic Boundary Layer Expedition (ABLE 3A): July-August 1988
}

\section{Citation}

Harriss, R. C., S. C. Wofsy, D. S. Bartlett, M. C. Shipham, D. J. Jacob, J. M. Hoell, R. J. Bendura, et al. 1992. "The Arctic Boundary Layer Expedition (ABLE 3A): July-August 1988." Journal of Geophysical Research 97 (D15): 16383. doi:10.1029/91jd02109.

\section{Published Version}

doi:10.1029/91 JD02109

\section{Permanent link}

http://nrs.harvard.edu/urn-3:HUL.InstRepos:14121861

\section{Terms of Use}

This article was downloaded from Harvard University's DASH repository, and is made available under the terms and conditions applicable to Other Posted Material, as set forth at http:// nrs.harvard.edu/urn-3:HUL.InstRepos:dash.current.terms-of-use\#LAA

\section{Share Your Story}

The Harvard community has made this article openly available.

Please share how this access benefits you. Submit a story.

\section{Accessibility}




\title{
The Arctic Boundary Layer Expedition (ABLE 3A): July-August 1988
}

\author{
R. C. Harriss, ${ }^{1}$ S. C. Wofsy, ${ }^{2}$ D. S. Bartlett, ${ }^{1}$ M. C. Shipham, ${ }^{3}$ D. J. Jacob, ${ }^{2}$ J. M. Hoell, Jr., ${ }^{3}$ \\ R. J. Bendura, ${ }^{3}$ J. W. Drewry, ${ }^{3}$ R. J. McNeal, ${ }^{4}$ R. L. Navarro, ${ }^{5}$ \\ R. N. GIDGE, ${ }^{5}$ AND V. E. RABINE ${ }^{5}$
}

\begin{abstract}
The Arctic Boundary Layer Expedition (ABLE 3A) used measurements from ground, aircraft, and satellite platforms to characterize the chemistry and dynamics of the lower atmosphere over Arctic and sub-Arctic regions of North America during July and August 1988. The primary objectives of ABLE 3A were to investigate the magnitude and variability of methane emissions from the tundra ecosystem, and to elucidate factors controlling ozone production and destruction in the Arctic atmosphere. This paper reports the experimental design for ABLE 3A and a summary of results. Methane emissions from the tundra landscape varied widely from -2.1 to $426 \mathrm{mg} \mathrm{CH}_{4} \mathrm{~m}^{-2} \mathrm{~d}^{-1}$. Soil moisture and temperature were positively correlated with methane emission rates, indicating quantitative linkages between seasonal climate variability and soil metabolism. Enclosure flux measurement techniques, tower-based eddy correlation, and airborne eddy correlation flux measurements all proved robust for application to methane studies in the tundra ecosystem. Measurements and photochemical modeling of factors involved in ozone production and destruction validated the hypothesized importance of low $\mathrm{NO}_{x}$ concentrations as a dominant factor in maintaining the pristine Arctic troposphere as an ozone sink. Stratospheric intrusions, long-range transport of mid-latitude pollution, forest fires, lightning, and aircraft are all potential sources of $\mathrm{NO}_{x}$ and $\mathrm{NO}_{y}$ to Arctic and sub-Arctic regions. ABLE $3 \mathrm{~A}$ results indicate that human activities may have already enhanced $\mathrm{NO}_{y}$ inputs to the region to the extent that the lifetime of $\mathrm{O}_{3}$ against photochemical loss may have already doubled. A doubling of $\mathrm{NO}_{x}$ concentration from present levels would lead to net photochemical production of $\mathrm{O}_{3}$ during summer months in the Arctic (Jacob et al., this issue (a)). The ABLE 3A results indicate that atmospheric chemical changes in the northern high latitudes may serve as unique early warning indicators of the rates and magnitude of global environmental change.
\end{abstract}

\section{INTRODUCTION}

The Arctic Boundary Layer Expedition (ABLE 3A) was conducted in Arctic and sub-Arctic regions of North America and Greenland during July and August 1988. This was the first comprehensive investigation of the sources, sinks, and distribution of trace gas and aerosol chemical species in a northern high-latitude region during summer months. The ABLE 3A experimental design placed emphasis on the role of biosphere-atmosphere interactions in determining the chemical composition of the troposphere and on processes which influence the tropospheric $\mathrm{O}_{3}$ budget (Figure 1). The suite of chemical species measured included the following gases: methane $\left(\mathrm{CH}_{4}\right)$, carbon monoxide $(\mathrm{CO})$, carbon dioxide $\left(\mathrm{CO}_{2}\right)$, nonmethane hydrocarbons (NMHC), acetic acid (HA), formic acid (HFo), nitric oxide (NO), nitrogen dioxide $\left(\mathrm{NO}_{2}\right)$, total "reactive" nitrogen gas $\left(\mathrm{NO}_{y}\right)$, nitric acid $\left(\mathrm{HNO}_{3}\right)$, peroxyacetyl nitrate (PAN), peroxypropionyl nitrate (PPN), ozone $\left(\mathrm{O}_{3}\right)$, and aerosol chemical composition and size distribution.

The ABLE $3 \mathrm{~A}$ is a component of the NASA Global Tropospheric Experiment (GTE) sponsored by the NASA

\footnotetext{
${ }^{1}$ Institute for the Study of Earth, Oceans and Space, University of New Hampshire, Durham.

${ }^{2}$ Harvard University, Cambridge, Massachusetts.

${ }^{3}$ Atmospheric Sciences Division, NASA Langley Research Center, Hampton, Virginia.

${ }^{4}$ Earth Science and Applications Division, National Aeronautics and Space Administration, Washington, D. C.

${ }^{5}$ NASA Wallops Flight Facility, Wallops Island, Virginia.

Copyright 1992 by the American Geophysical Union.

Paper number 91JD02109.

0148-0227/92/91JD-02109\$05.00
}

Tropospheric Chemistry Program [McNeal et al., 1983]. Previous ABLE expeditions have reported on the chemistry of North African dust and marine air over the tropical Atlantic [e.g., Ferek et al., 1986; Talbot et al., 1986] and on air chemistry over the tropical rain forests of Guyana and Brazil [e.g., Gregory et al., 1986; Harriss et al., 1988, 1990]. A second expedition to the northern high latitudes (ABLE 3B) was conducted jointly with the Canadian Northern Wetlands Project during July-August 1990.

This paper reports the overall experimental design for ABLE $3 \mathrm{~A}$ and includes a brief overview of results. A following series of papers report the detailed results of individual studies.

\section{Arctic and Boreal Region Air}

Arctic and boreal regions $\left(>50^{\circ} \mathrm{N}\right)$ are uniquely important to tropospheric chemistry for at least two reasons: (1) these regions include approximately $27 \%$ of the world's soil carbon [Post et al., 1982]. The exchange of this carbon between soils and the atmosphere, as $\mathrm{CO}_{2}$ and $\mathrm{CH}_{4}$, is influenced by climate variability [e.g., Billings, 1987]. In a "global warming" era these environments may be "feedback" regions which influence rates of climatic change. (2) Even the most remote wilderness areas of the region are showing indications of air pollution derived from long-range transport from mid-latitude source emissions. During late winter and early spring, meteorological conditions are particularly favorable for midtropospheric air masses to track across industrialized regions and into the Arctic (see Barrie [1986] for a review). It is particularly important to understand both direct and indirect impacts of long-range transport of pollutants on the chemistry of high-latitude air masses. Direct impacts could 


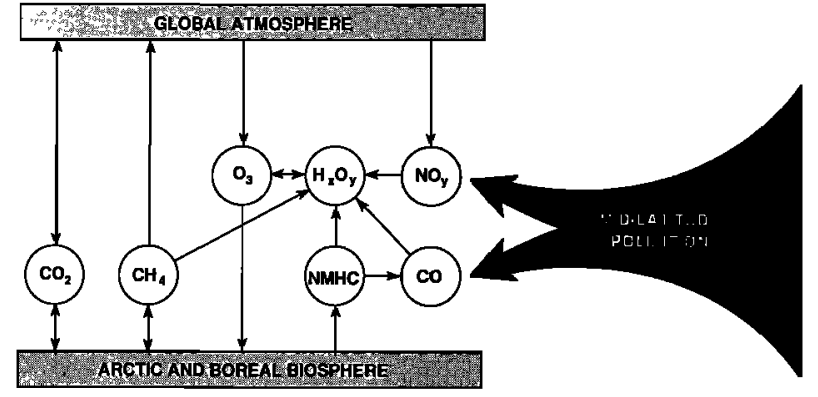

Fig. 1. A schematic illustration of interactions of the biosphere, climate, and long-range transport of pollutants as sources and/or sinks for atmospheric trace gases in northern high-latitude regions.

include detrimental effects on Arctic ecosystems. Or increased deposition of nitrogen could enhance biosphereatmosphere gas exchange with subsequent effects on atmospheric gases like $\mathrm{CO}_{2}$ and $\mathrm{CH}_{4}$. Another concern is changes in the chemistry of "baseline" Arctic air, which is a major source region for north-to-south flow across North America and other regions. Thus, information on Arctic and subArctic air chemistry is essential to resolving controversial issues like natural versus human contributions to acid rain and ozone pollution in the mid-latitudes.

\section{Chemistry-Climate Connection}

The ABLE 3A program was focused on high-latitude $\left(>50^{\circ} \mathrm{N}\right)$ regions because almost all climate models and paleoenvironmental studies indicate that these regions are especially sensitive to climatic change. Several review papers have appeared recently which provide excellent summaries of the theoretical basis for predicting a tropospheric warming trend in response to increasing atmospheric trace gas concentrations [e.g., Dickinson, 1986; Ramanathan et al., 1987]. There are also some empirical data which indicate increasing permafrost temperatures [Lachenbruch and Marshall, 1986], suggesting that certain regions of the highlatitude biosphere may be experiencing the early stages of a warming. Biospheric responses to a variable climate are feedback processes which could accelerate or modulate rates of climate change. Examples of potential feedbacks have been documented by direct measurement of trace gas exchange rates in response to seasonal climate changes, and by inference from correlations of trace gas concentrations and isotopically derived temperature records in ice cores. For example, studies of variations of trace gases of biospheric origin such as $\mathrm{CO}_{2}$ and $\mathrm{CH}_{4}$ in ice cores suggest that atmospheric composition has been closely coupled to atmospheric temperature in polar regions for at least the past 160,000 years [e.g., Raynaud et al., 1988; Chappellaz et al., 1990].

A more direct indication of initial feedbacks to climate change can be derived from field and experimental studies of $\mathrm{CH}_{4}$ exchange rates between northern peatland soils and the atmosphere in response to seasonal variations in soil temperature and moisture. In both tundra and boreal environments $\mathrm{CH}_{4}$ flux to the atmosphere has been shown to be sensitive to seasonal climatic variations [e.g., Sebacher et al., 1986; Moore and Knowles, 1987; Crill et al., 1988; Whalen and Reeburgh, 1988; Bartlett et al., this issue]. Methane flux increases in response to increasing soil tem- peratures in water-saturated organic soils. Soil drying decreases $\mathrm{CH}_{4}$ emissions. Experimental studies on tundra soil cores indicate the opposite behavior for $\mathrm{CO}_{2}$ flux; aerobic decomposition which produces $\mathrm{CO}_{2}$ is the dominant process in dry soils [e.g., Billings, 1987]. Thus, a warmer, wetter climate might enhance $\mathrm{CH}_{4}$ flux from northern peatland environments. A warmer, dryer climate might result in reduced $\mathrm{CH}_{4}$ emissions and enhanced $\mathrm{CO}_{2}$ flux.

Potential trace gas feedbacks to climate change in northern tundra environments can be expected to operate on at least three time scales: (1) Changes in $\mathrm{CH}_{4}$ flux from the near-surface "active" soil layer in response to seasonal or interannual climate variations will be the initial signal of a biospheric feedback. (2) Gradual climate change on decadal to century time scales could alter permafrost, a warming trend would release trapped $\mathrm{CH}_{4}$ from the permafrost and increase the depth of the seasonal active layer. (3) A long-term dramatic warming of the Arctic (e.g., an ice-free condition) could lead to a release of $\mathrm{CH}_{4}$ from presently frozen methane hydrates found at considerable depth below the surface. The ABLE 3 is focused on understanding the "early warning" response of the near-surface, organic active layer to climate variability.

Several preliminary modeling studies have also been conducted to explore potential interactions between climate change and atmospheric chemistry [e.g., Hameed and Cess, 1983; Khalil and Rasmussen, 1989]. These studies also indicate that climate-induced feedbacks from natural soils could potentially influence the global $\mathrm{CH}_{4}$ budget.

The ABLE 3A has obtained regional-scale empirical data on trace gas exchanges between northern ecosystems and the atmosphere, which will permit a more detailed analysis of potential biosphere-atmosphere feedback processes in response to climate variability. Three independent approaches to $\mathrm{CH}_{4}$ flux measurement were used to define the characteristic temporal and spatial variability for the YukonKuskokwim tundra ecosystem, Alaska. Ground-based enclosure and eddy correlation measurements were used to characterize temporal variability, individual landscape elements as sources or sinks, and integrated flux from the local area. An airborne eddy correlation measurement program was used to characterize spatial variability in $\mathrm{CH}_{4}$ flux at the regional scale.

\section{High-Latitude Air Pollution: Magnitude and Impacts}

The large-scale pollution of the Arctic troposphere by long-range transport of pollutants from industrial regions during late winter and early spring months is well documented [e.g., Schnell, 1984; Barrie, 1986; Stonehouse, 1986; Lowenthal and Rahn, 1985]. During these "Arctic haze" pollution events the buildup of aerosol constituents, sulfur dioxide, and PAN has been observed [e.g., Barrie and Hoff, 1985; Bottenheim et al., 1986]. At the time of Arctic sunrise, significant perturbations in the chemistry of the boundary layer have been observed: $\mathrm{O}_{3}$ concentrations decrease, gaseous halogens increase, and aerosol pollutant species decrease [Barrie et al., 1989]. To date, there have been no comprehensive studies of the chemistry of the Arctic troposphere during summer months. Observations during the summer are critical to an assessment of the full impact of the accumulated winter/spring pollutant loadings, and to determine if significant long-range transport and injection of pollutants occur during these months. 
Observations at a few ground-based monitoring sites have indicated that concentrations of aerosols are at a minimum during summer periods [e.g., Bodhaine, 1986]. However, ground-based monitoring stations at Arctic sites are influenced by frequent stratus cloud cover and may not be a good indicator of overall tropospheric air chemistry. Evidence gathered in ABLE 3A indicates that the stratus cloud decks common over the Arctic during summer months may filter out soluble aerosol species before they reach ground level [e.g., Talbot et al., this issue].

The observation of a possible increasing trend in surface $\mathrm{O}_{3}$ at Barrow, Alaska [Oltmans and Komhyr, 1986] is a potential indicator of an increasing degree of Arctic pollution. However, the $\mathrm{O}_{3}$ concentration at any individual site will be influenced by a variety of meteorological and chemical factors. The ABLE $3 \mathrm{~A}$ placed special emphasis on identifying the range of variables which might have a significant influence on the tropospheric $\mathrm{O}_{3}$ budget in the Barrow region during the summer period.

A component of $\mathrm{ABLE} 3 \mathrm{~A} \mathrm{O}_{3}$ studies was to determine the sources of nitrogen oxides $\left(\mathrm{NO}_{x}\right)$ and total reactive nitrogen $\left(\mathrm{NO}_{y}\right)$ to the Arctic troposphere. Previous studies indicated that primary production in many biological environments in the Arctic is limited by inadequate levels of available nitrogen during summer months [e.g., Van Cleve and Alexander, 1981]. These results suggest that surface environments should be a net sink for $\mathrm{NO}_{x}$ and $\mathrm{NO}_{y}$. Unider natural conditions, the Arctic region should be an important low- $\mathrm{NO}_{x}$ region for testing photochemical theory on the role of $\mathrm{NO}_{x}$ in $\mathrm{O}_{3}$ production and destruction processes. However, the alternate possibility existed that a reservoir of atmospheric reactive nitrogen accumulated during winter and spring months from mid-latitude pollution sources could provide a source of $\mathrm{NO}_{x}$ to influence photochemical $\mathrm{O}_{3}$ chemistry during summer months. Enhanced deposition of nitrogen to the Arctic biosphere from mid-latitude pollution sources could also stimulate primary production and alter biosphere-atmosphere exchange rates of other trace gases like $\mathrm{CO}_{2}$ and $\mathrm{CH}_{4}$.

Another characteristic of the Arctic tundra ecosystem important to ABLE 3A objectives is the paucity of plant species known to emit isoprene and other reactive nonmethane hydrocarbon species which are important in $\mathrm{O}_{3}$ chemistry. As a long-term strategy, the ABLE missions are designed to study $\mathrm{O}_{3}$ production and destruction processes in atmospheric boundary layer environments which have characteristics of low $\mathrm{NO}_{x}$ /low NMHC (tundra), low $\mathrm{NO}_{x}$ / high NMHC (boreal forest), low $\mathrm{NO}_{x}$ /high NMHC (wet season tropical forest), intermediate $\mathrm{NO}_{x}$ /high $\mathrm{NMHC}$ (dry season, unpolluted tropical forest), high $\mathrm{NO}_{x} /$ high $\mathrm{NMHC}$ (polluted tropical and boreal forests), and high $\mathrm{NO}_{x} /$ low NMHC (polluted tundra environments). Results from several of these categories are reported in ABLE 2 publications (Journal of Geophysical Research, volume 93, pages 1349 1624,1988 ; and volume 95 , pages $16,721-17,050,1990$ ) and in the present issue.

\section{APPROACH}

The scientific objectives of ABLE 3A were accomplished through a coordinated program of chemical and meteorological measurements at surface sites in Alaska and on the NASA Lockheed Electra research aircraft. The expedition was conducted during July and August 1988. A complimentary program of surface-based biogeochemical studies, termed the Biospheric Research on Emissions from Wetlands (BREW), supported by the NASA Biospherics Research Program, was conducted in Bethel, Alaska, during the period of the ABLE 3A. Investigators sponsored by the NASA Interdisciplinary Program also participated in the expedition. A list of principal investigators, institutions, and measurements is presented in Table 1 .

\section{Aircraft Experiments}

The centerpiece of ABLE $3 \mathrm{~A}$ was a series of research flights with the instrumented NASA Electra (Figure 2). The flights were divided into four generic types of experiments: (1) Boundary layer survey studies determined the regional horizontal and vertical distribution of trace gas and aerosol species over tundra environments to explore the qualitative effects of biosphere-atmosphere exchange versus atmospheric transport processes on the chemical composition of the atmospheric mixed layer and overlying free troposphere. (2) Flux measurements were conducted over tundra environments to quantify exchange rates for $\mathrm{CH}_{4}, \mathrm{CO}$, and $\mathrm{O}_{3}$ at incremental scales of approximately $50-150 \mathrm{~km}$ over a total of up to $2000 \mathrm{~km}$ per experiment. (3) Several missions were devoted to determining the large-scale distribution of gas and aerosol species over ice and oceanic environments upwind of tundra, with flight lines along a sea or ice to land gradient. These missions also provided an excellent qualitative indication of gas and aerosol source/sink processes associated with different surface environments. (4) Several missions, and transit flights between bases, were devoted primarily to characterizing mid-tropospheric variability of gas and aerosol species for investigation of long-range transport of pollutants to the study regions and tropospheric photochemical processes. A schematic illustration of these generic flight patterns is shown in Figure 3.

The areas studied by intensive aircraft missions are shown in Figure 4. The characteristics of each mission are summarized in Table 2.

In situ measurements of most of the trace gas and aerosol chemical species discussed in the above sections are available for all of the flights listed in Table 2. The twodimensional distribution of aerosol and $\mathrm{O}_{3}$ from the surface to the tropopause was measured along each flight path using a UV Differential Absorption Lidar (DIAL) described by Browell et al. [this issue]. The UV DIAL also provides information on cloud distribution and on mixed layer dynamics.

Aircraft research missions were conducted from bases in Barrow, Alaska (flights 6-12), Bethel, Alaska (flights 14-21, 25-26), Cold Bay, Alaska (flights 22-24), and Thule, Greenland (flight 29). Flights 30-33 from Thule, Greenland, to Wallops Island, Virginia, on August 15-16, 1988, included vertical profiles along the flight track to determine latitudinal distributions of trace gas and aerosol species as a function of altitude. Flights 1-5 were constant altitude transits between Wallops Island, Thunder Bay, Churchill, Thule, Fairbanks, and Barrow (Figure 4).

\section{Ground-Based Experiments}

The extensive peatland environments in the YukonKuskokwim Delta region of Alaska, overflown during mis- 
TABLE 1. Principal Investigators Participating in ABLE 3A

\begin{tabular}{|c|c|c|}
\hline Investigator & Institution & Investigation \\
\hline \multicolumn{3}{|c|}{ Tropospheric Chemistry Program } \\
\hline John Barrick & NASA Langley Research Center & Airborne meteorological/position data (a) \\
\hline John Bradshaw & Georgia Institute of Technology & Nitric oxide, nitrogen dioxide, $\mathrm{NO}_{\mathrm{y}}$ (a) \\
\hline Edward V. Browell & NASA Langley Research Center & Aerosols, ozone profiles (a) \\
\hline David R. Fitzjarrald & State University of New York at Albany & Micrometeorogical studies (s) \\
\hline Gerald L. Gregory & NASA Langley Research Center & Ozone, aerosol size (a) \\
\hline Robert C. Harriss & NASA Langley Research Center & Carbon dioxide/Mission Scientist (a) \\
\hline Paul Kebabian & Aerodyne Research, Inc. & Methane (s) \\
\hline Enio Pereira & Instituto de Pesquisas Espacials, Brazil & Radon (a) \\
\hline John Ritter & NASA Langley Research Center & Eddy correlation flux $\left(\mathrm{CO}, \mathrm{CH}_{4}, \mathrm{O}_{3}, \mathrm{H}_{2}, \mathrm{H}_{2} \mathrm{O}\right)$ (a) \\
\hline F. Sherwood Rowland & University of California at Irvine & Nonmethane hydrocarbons (a) \\
\hline Glen W. Sachse & NASA Langley Research Center & Carbon monoxide, methane (a) \\
\hline Hanwant Singh & NASA Ames Research Center & PAN, $\mathrm{PPN}, \mathrm{CCl}_{4}$ (a) \\
\hline Robert W. Talbot & NASA Langley Research Center & Aerosol composition, nitric and organic acids (a) \\
\hline Steven C. Wofsy & Harvard University & Carbon dioxide (a) \\
\hline & & $\begin{array}{l}\left.\text { Nitrogen species (NO, } \mathrm{NO}_{2}, \mathrm{NO}_{\mathrm{y}}\right)(\mathrm{s}) \\
\text { Eddy correlation flux }\left(\mathrm{O}_{3}, \mathrm{CO}_{2}, \mathrm{NO}_{\mathrm{y}}\right)(\mathrm{s})\end{array}$ \\
\hline \multicolumn{3}{|c|}{ Biospheric Research Program (s) } \\
\hline David S. Bartlett & NASA Langley Research Center & $\mathrm{CO}_{2}$ exchange/Mission scientist \\
\hline Michael Hardisky & University of Scranton & Below-ground biomass/radar \\
\hline Karen B. Bartlett & College of William and Mary & Methane flux \\
\hline Mark Hines & University of New Hampshire & Sulfur flux \\
\hline Gary King & University of Maine & Methane oxidation \\
\hline Vic Klemas & University of Delaware & Below-ground biomass/radar \\
\hline Christopher Martens & University of North Carolina & Radon/ $/ \mathrm{CH}_{4}$ Isotopes \\
\hline \multicolumn{3}{|c|}{ Interdisciplinary Program $(s)$} \\
\hline Patrick Crill & University of New Hampshire & Methane flux \\
\hline
\end{tabular}

(a), airborne; (s), surface.

sions conducted from Bethel, were selected for detailed ground-based studies of trace gas exchange between the biosphere and the atmosphere. The region includes approximately 9 million hectares of lowland tundra, underlain by permafrost, and containing a large number of shallow lakes. Vegetated areas are covered by a moss/lichen/dwarf shrub community on relatively well-drained soils and by a herbaceous community on wet soils (Figures $5 a$ and $5 b$ ).

Data on the distribution of vegetation types and other environmental characteristics were available at a number of spatial scales. Land cover of the entire delta region has been mapped at $80-\mathrm{km}$ resolution by the U.S. Geological Survey using Landsat imagery. More detailed characterization of local areas was conducted during the analysis of ABLE 3A data using System Probatoire d'Observation de la Terre (SPOT) imagery, which has $15-\mathrm{m}$ resolution.

The two major components of the ground-based research program were (1) measurements of fluxes, total storage, and isotopic characteristics of biogenic trace gases using enclosures and soil sampling techniques. (2) Flux and ambient atmospheric concentrations of trace gases were also measured using micrometeorological and eddy correlation techniques to obtain time series of surface/atmosphere exchange.

The objective of enclosure measurements was to quantify relationships of biogenic gas sources and sinks along major environmental gradients representative of the YukonKuskokwim tundra. Topography and resulting surface and soil water conditions exert major controls over vegetation and soil composition (Figure $5 a$ ). These relationships were also hypothesized to mediate trace gas fluxes. Satellite remote sensing of the spatial distribution of surface environments was used to extrapolate point measurements of flux to the regional tundra environment [e.g., Bartlett et al., this issue; Whiting et al., this issue]. Relationships of flux with important physical variables such as temperature and light level were also studied. The trace gas species examined were $\mathrm{CH}_{4}$ [Bartlett et al., this issue], $\mathrm{CO}_{2}$ [Whiting et al., this issue], and several sulfur compounds [Hines and Morrison, this issue]. Soil profiles and depth to permafrost along selected transects were obtained using ground-penetrating radar techniques by Doolittle et al. [1990]. Studies were conducted in undisturbed sites accessible by road from Bethel, and in the area of the ABLE $3 \mathrm{~A}$ micrometeorological tower.

The ABLE 3A micrometeorological tower facility is shown in Figure 6. The tower was located approximately $50 \mathrm{~km} \mathrm{WNW}$ of Bethel $\left(61^{\circ} \mathrm{N}, 162.5^{\circ} \mathrm{W}\right)$ and was accessible by float plane. Climatological data were used to site the tower in a location which would be subject to minimal local pollution effects.

Ground-based measurements were carefully coordinated with aircraft overflights to provide data for comparing estimates of $\mathrm{CH}_{4}$ emissions from local to regional scales based on enclosure, tower, and airborne eddy correlation methods.

In addition to ABLE $3 \mathrm{~A}$ investigators, the ground-based program included investigators sponsored by BREW and the NASA Interdisciplinary Research Program (Table 1).

\section{Meteorological Measurements}

Meteorological forecasts during the ABLE field expedition were provided by a team of meteorologists stationed at the Anchorage National Weather Service Office. The Anchorage office receives extensive data, including both GOES and NOAA 9 polar orbitor imagery, all National Weather Service products, statewide surface observations, and a host of specialized computer-generated products tailored to the Alaska region. 


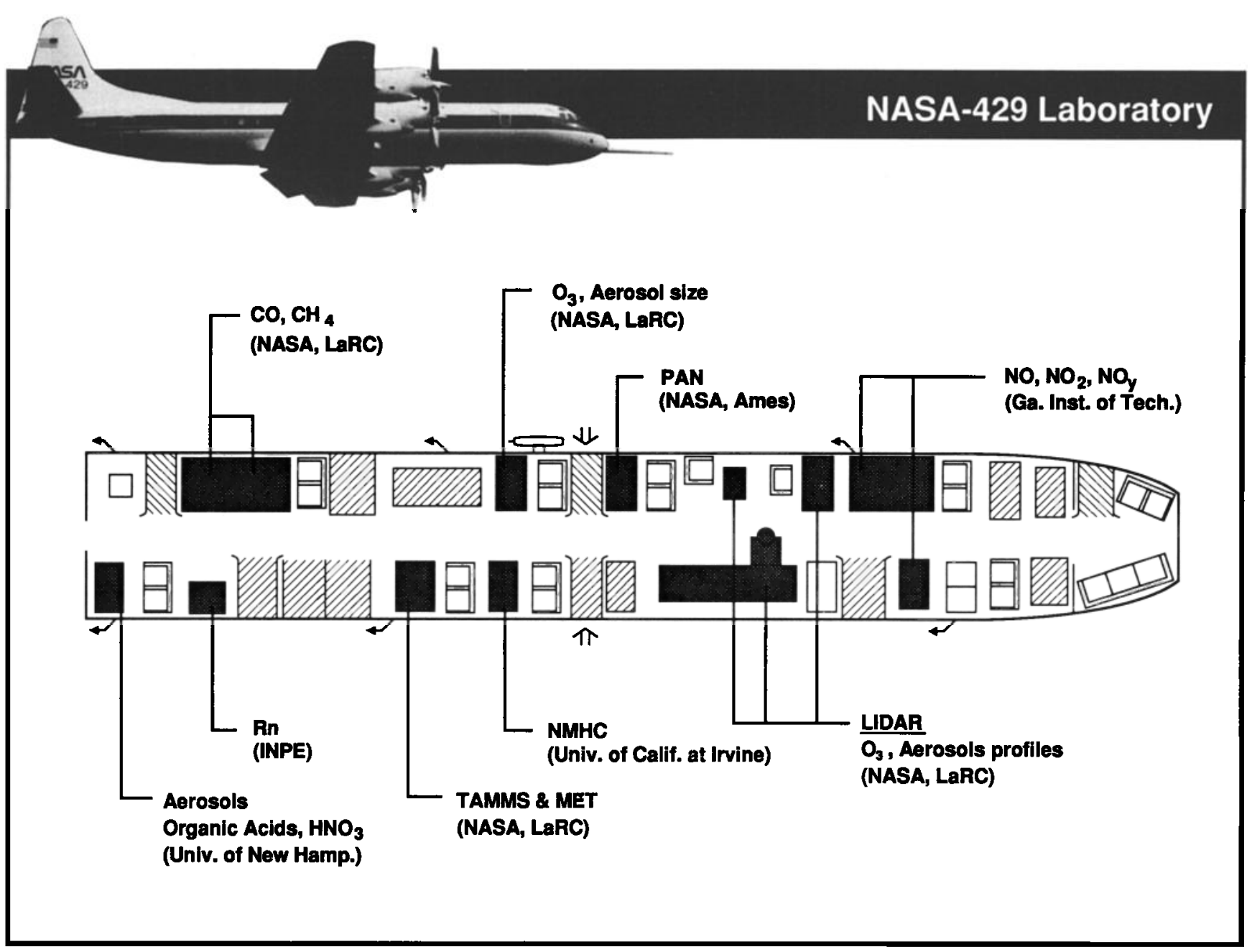

Fig. 2. The NASA Electra research aircraft and a diagram of the location of instrumentation during ABLE $3 A$.

In addition, a Micro-VAX-II computer from NASA was used to receive domestic, international, and model data through a satellite downlink from Zeypher Weather, Inc. This allowed a host of additional products to be generated and stored in near real time, including soundings, potential temperature time-height cross sections, and 12- to 48-hour forecast wind fields. All generated products were faxed to the aircraft location on a twice daily basis. Forecasts were updated via telephone and were available on an as needed basis.

Postmission meteorological analyses included a comparison of weather during the study period to climatological means, calculation of isentropic trajectories for air mass flow and source regions associated with each aircraft mission, and compilation of the active forest fires in Alaska during ABLE 3A. A summary of meteorological methods and results for $A B L E 3 A$ is provided by Shipham et al. [this issue].

\section{OVERVIEW OF RESULTS}

In this brief overview of results, we highlight selected findings from individual investigations which relate directly to the primary objectives of the expedition. It is hoped that this summary will serve the reader who may not be able to pursue study of the entire collection of ABLE $3 \mathrm{~A}$ papers.
This summary also serves as a guide to individual papers, which discuss the details of specific factors controlling the distribution of any particular trace gas or aerosol constituent.

\section{Methane Sources and Sinks}

Water-saturated soils and lake sediments are the primary sources of $\mathrm{CH}_{4}$ in the Arctic and sub-Arctic landscapes studied in ABLE 3A. Dry tundra soils can reduce $\mathrm{CH}_{4}$ concentrations below ambient concentrations in the atmospheric mixed layer, acting as a weak sink for tropospheric $\mathrm{CH}_{4}$ [Whalen and Reeburgh, 1990]. In the YukonKuskokwim Delta environments studied in ABLE $3 \mathrm{~A}, \mathrm{CH}_{4}$ exchange rates ranged widely from $-2 \mathrm{mg} \mathrm{m}^{-2} \mathrm{~d}^{-1}$ (net consumption of atmospheric $\mathrm{CH}_{4}$ ) to net emissions as high as $400 \mathrm{mg} \mathrm{m}^{-2} \mathrm{~d}^{-1}$ [Bartlett et al., this issue].

A synthesis of published $\mathrm{CH}_{4}$ flux data from high-latitude tundra sites by Bartlett et al. [this issue] was used to calculate an annual flux of approximately $11 \pm 4 \mathrm{Tg} \mathrm{CH}_{4}$ from the global tundra ecosystem. Scaling up the $\mathrm{CH}_{4}$ flux data from the ABLE $3 \mathrm{~A}$ micrometeorological tower produced an estimate of approximately $11 \mathrm{Tg} \mathrm{CH}_{4} \mathrm{yr}^{-1}$ from global tundra [Fan et al., this issue]. Most previous estimates centered between 20 and $40 \mathrm{Tg} \mathrm{yr}^{-1}$ [e.g., Sebacher et al., 1986; Whalen and Reeburgh, 1988]. It is significant to 


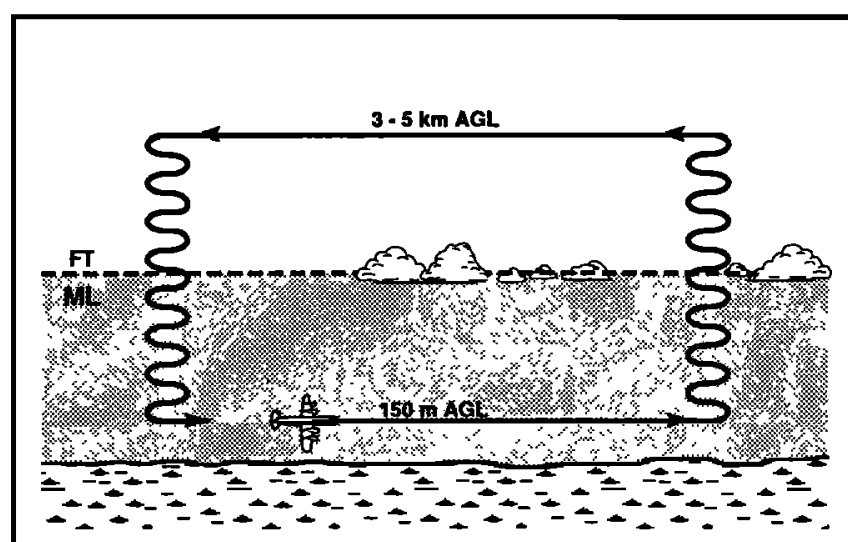

(a) SURFACE EXCHANGE STUDIES

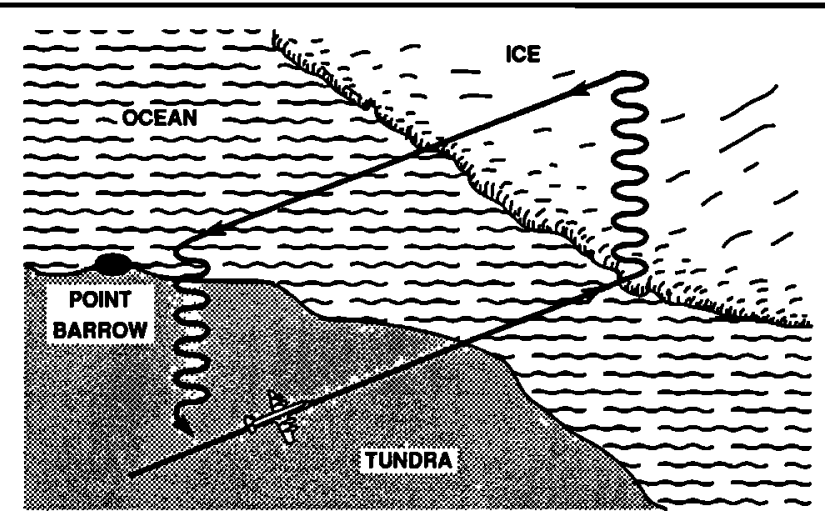

(c) LAND-OCEAN-ICE GRADIENT STUDIES

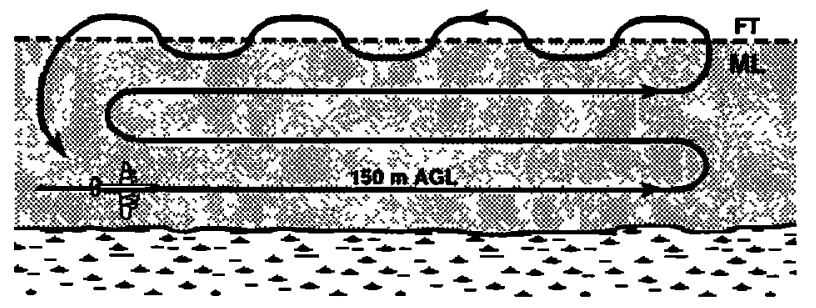

(b) FLUX STUDIES

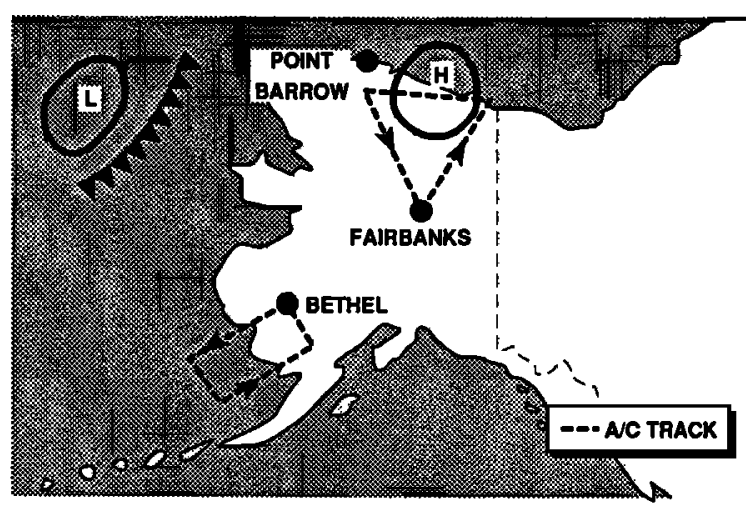

(d) PHOTOCHEMICAL STUDIES

Fig. 3. Simplified illustrations of flight profiles used in ABLE 3A.

note that these new, lower estimates of the tundra $\mathrm{CH}_{4}$ source are very compatible with the preferred estimate derived with a global modeling technique [Fung et al., 1991].

The dominant factors determining the magnitude of $\mathrm{CH}_{4}$ flux were soil moisture and soil temperature. Watersaturated soils typically emitted $\mathrm{CH}_{4}$ at rates more than an order of magnitude greater than dry soils (Figure 7). The sensitivity of $\mathrm{CH}_{4}$ flux rates from both saturated and moist

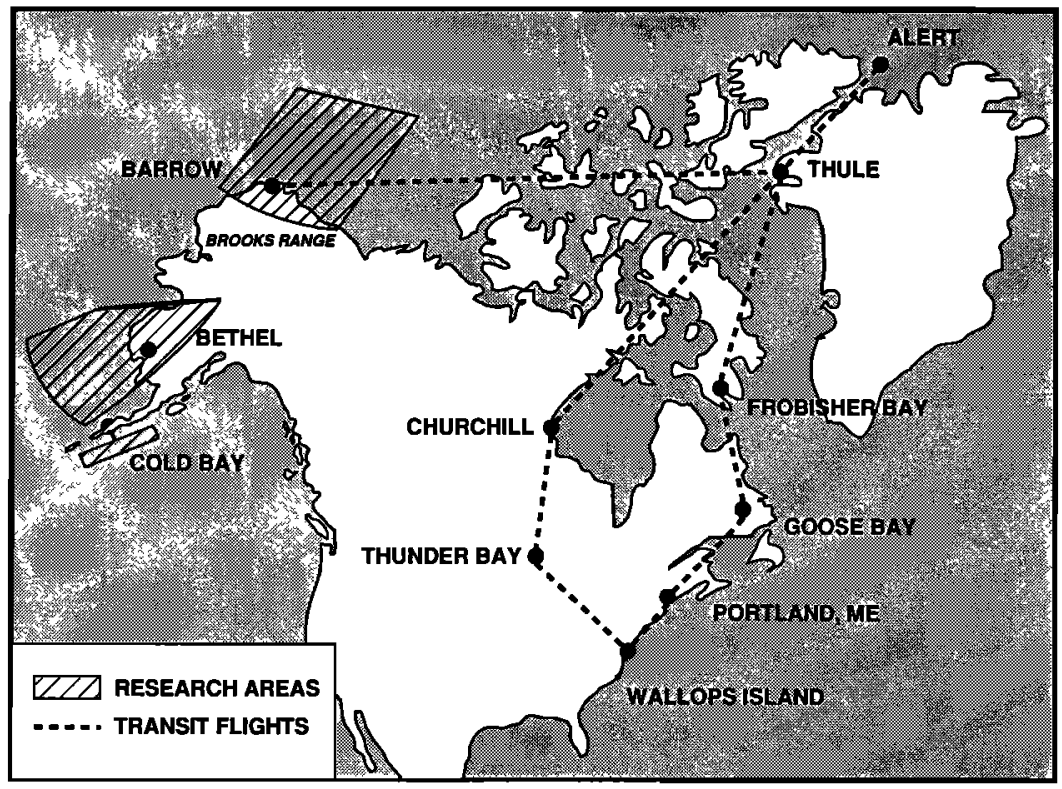

Fig. 4. Map of the regions studied by ABLE 3A. 
TABLE 2. Summary of the Flights Conducted During the ABLE 3A Expedition

\begin{tabular}{|c|c|c|c|c|c|c|}
\hline \multirow{2}{*}{$\begin{array}{l}\text { Mission } \\
\text { Number }\end{array}$} & \multirow[b]{2}{*}{ Flight Date } & \multicolumn{2}{|r|}{ Departure } & \multicolumn{2}{|r|}{ Arrival } & \multirow[b]{2}{*}{ Purpose } \\
\hline & & Time & Location & Time & Location & \\
\hline 1 & July 7 & 1312 & NASA Wallops Island & 1700 & Thunder Bay & Mid-troposphere distributions \\
\hline 2 & July 7 & 1813 & Thunder Bay & 2108 & Churchill & Mid-troposphere distributions \\
\hline 3 & July 8 & 1356 & Churchill & 1845 & Thule & Mid-troposphere distributions \\
\hline 4 & July 9 & 1250 & Thule & 1844 & Fairbanks & Mid-troposphere distributions \\
\hline 5 & July 10 & 1951 & Fairbanks & 2329 & Barrow & Mid-troposphere distributions \\
\hline 6 & July 12-13 & 2332 & Barrow & 0304 & Barrow & Correlations \\
\hline 7 & July $13-14$ & 1945 & Barrow & 0043 & Barrow & Boundary layer composition \\
\hline 8 & July 15-16 & 2033 & Barrow & 0046 & Barrow & Boundary layer composition \\
\hline 9 & July 17 & 1756 & Barow & 2309 & Barrow & Vertical distributions \\
\hline 10 & July $18-19$ & 1925 & Barrow & 0048 & Barrow & Flux measurements \\
\hline 11 & July $19-20$ & 2024 & Barrow & 0153 & Barrow & Vertical distributions \\
\hline 12 & July $21-22$ & 2303 & Barrow & 0349 & Barrow & Vertical distributions \\
\hline 13 & July 24 & 1801 & Barrow & 2343 & Bethel & Mid-troposphere distributions \\
\hline 14 & July $26-27$ & 2007 & Bethel & 0033 & Bethel & Vertical distributons \\
\hline 15 & July $27-28$ & 2351 & Bethel & 0503 & Bethel & Vertical distributions/correlations \\
\hline 16 & July $28-29$ & 1955 & Bethel & 0107 & Bethel & Flux measurements \\
\hline 17 & July $29-30$ & 1859 & Bethel & 0016 & Bethel & Land-sea interface \\
\hline 18 & July 31 & 1707 & Bethel & 2214 & Bethel & Flux measurements \\
\hline 19 & Aug. 2-3 & 1855 & Bethel & 0010 & Bethel & Land-sea interface \\
\hline 20 & Aug. 3 & 1800 & Bethel & 2220 & Bethel & Vertical distributions \\
\hline 21 & Aug. 4 & 0001 & Bethel & 0404 & Bethel & Vertical distributions \\
\hline 22 & Aug. 7 & 1902 & Bethel & 2157 & Cold Bay & Mid-troposphere distributions \\
\hline 23 & Aug 7-8 & 2329 & Cold Bay & 0419 & Cold Bay & Vertical distributions \\
\hline 24 & Aug. 8 & 2206 & Cold Bay & 2331 & Bethel & Mid-troposphere distributions \\
\hline 25 & Aug. 9 & 0131 & Bethel & 0645 & Bethel & Land-sea interface \\
\hline 26 & Aug. 9-10 & 2057 & Bethel & 0156 & Bethel & Flux measurements \\
\hline 27 & Aug. $11-12$ & 2136 & Bethel & 0015 & Barrow & Mid-troposphere distributions \\
\hline 28 & Aug. 12 & 1723 & Barrow & 2224 & Thule & Mid-troposphere distributions \\
\hline 29 & Aug. 13 & 1330 & Thule & 1836 & Thule & Mid-troposphere distributions \\
\hline 30 & Aug. 15 & 1200 & Thule & 1636 & Frobisher Bay & Mid-troposphere distributions \\
\hline 31 & Aug. 15 & 1719 & Frobisher Bay & 2108 & Goose Bay & Mid-troposphere distributions \\
\hline 32 & Aug. 16 & 1333 & Goose Bay & 1750 & Portland & Mid-troposphere distributions \\
\hline 33 & Aug. 17 & 1340 & Portland & 1708 & NASA Langley & Mid-troposphere distributions \\
\hline
\end{tabular}

Time is GMT.

tundra to variations in soil temperature are also shown in Figure 7 . In wet meadow tundra a $2^{\circ} \mathrm{C}$ increase in temperature at 10 - to $20-\mathrm{cm}$ soil depth increases the $\mathrm{CH}_{4}$ flux to the atmosphere approximately $120 \%$. These results together with similar characterizations at other Arctic and boreal sites [e.g., Crill et al., 1988; Whalen and Reeburgh, 1988] indicate that a warming of several degrees centigrade during summer months in northern high latitudes could possibly produce a detectable increase in regional tropospheric ambient $\mathrm{CH}_{4}$ concentrations. A long-term monitoring program for ambient $\mathrm{CH}_{4}$ at sites downwind of extensive tundra could possibly provide an "early warning" of climate change effects in the Arctic.

\section{Sources and Chemistry of Nitrogen Gases}

The ABLE 3A results indicate that pollutant emissions from human activities in mid-latitude regions and emissions

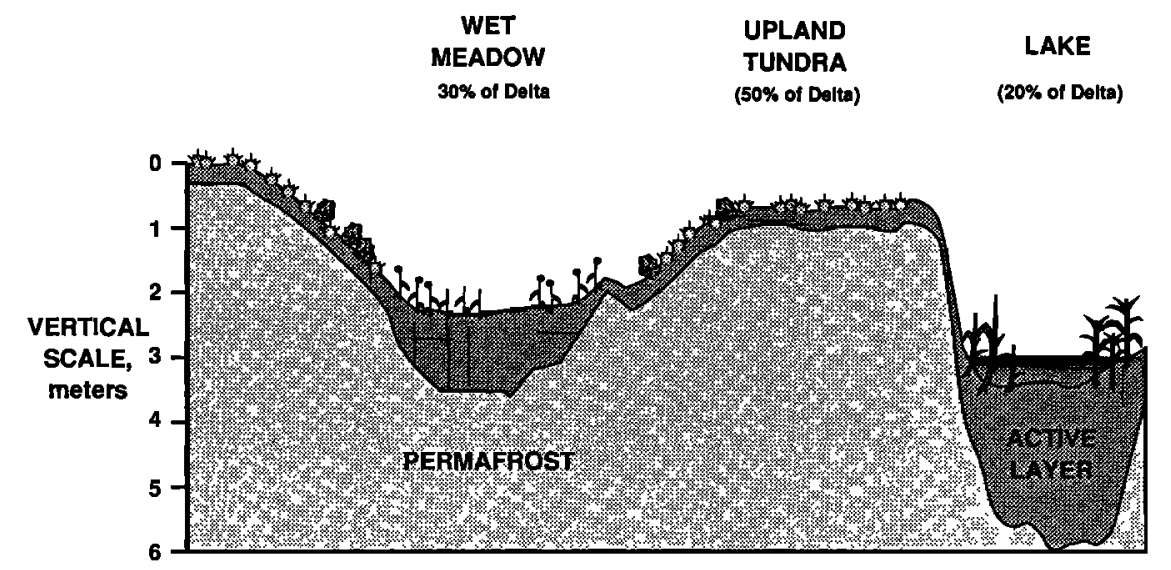

Fig. 5a. Schematic cross section of the type of environments studied by aircraft and ground-based investigations in the Yukon-Kuskokwim Delta region of Alaska during ABLE 3A. 


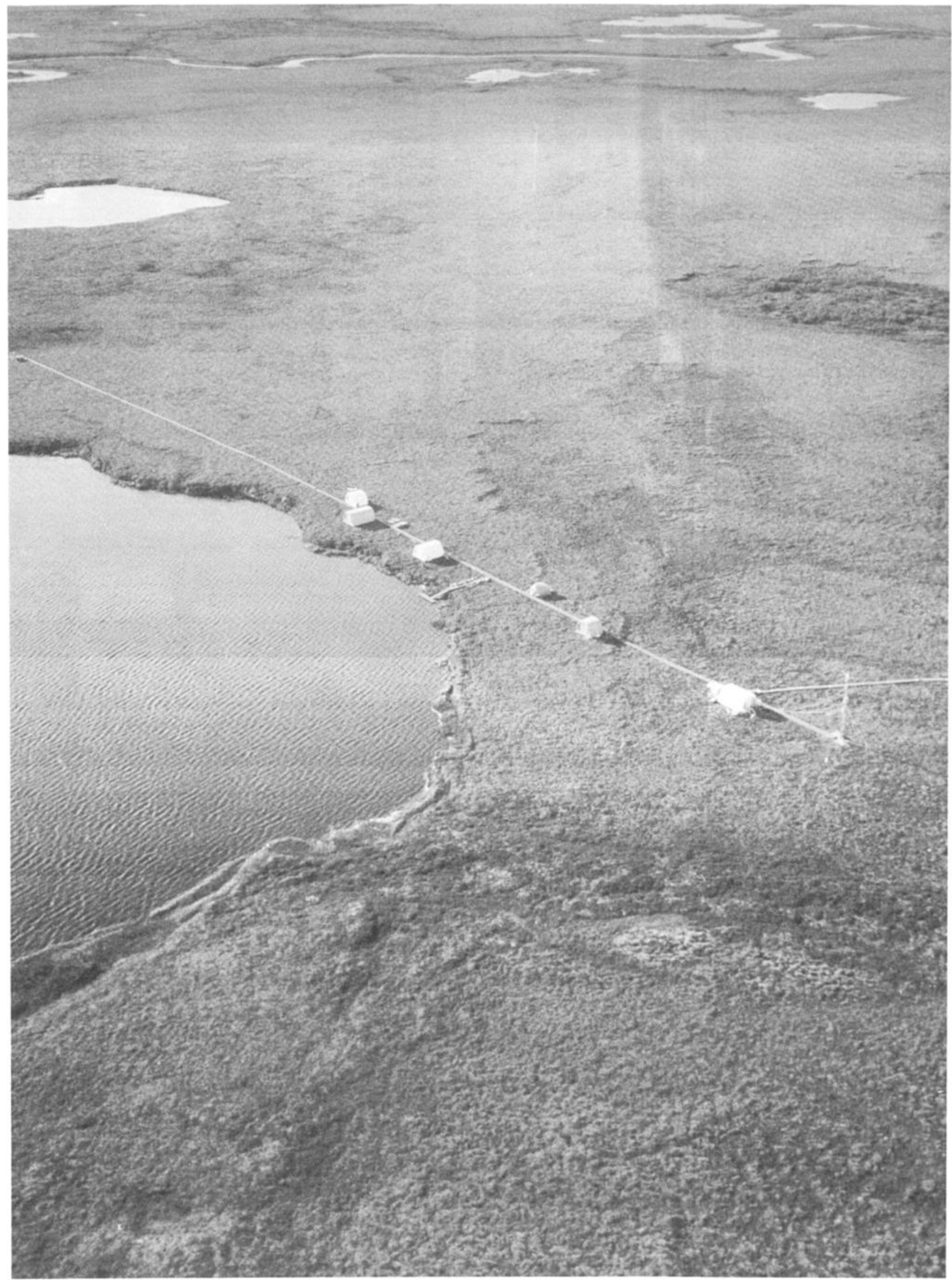

Fig. 5b. An aerial perspective of the Yukon-Kuskokwim Delta, including the ABLE 3A ground site. 


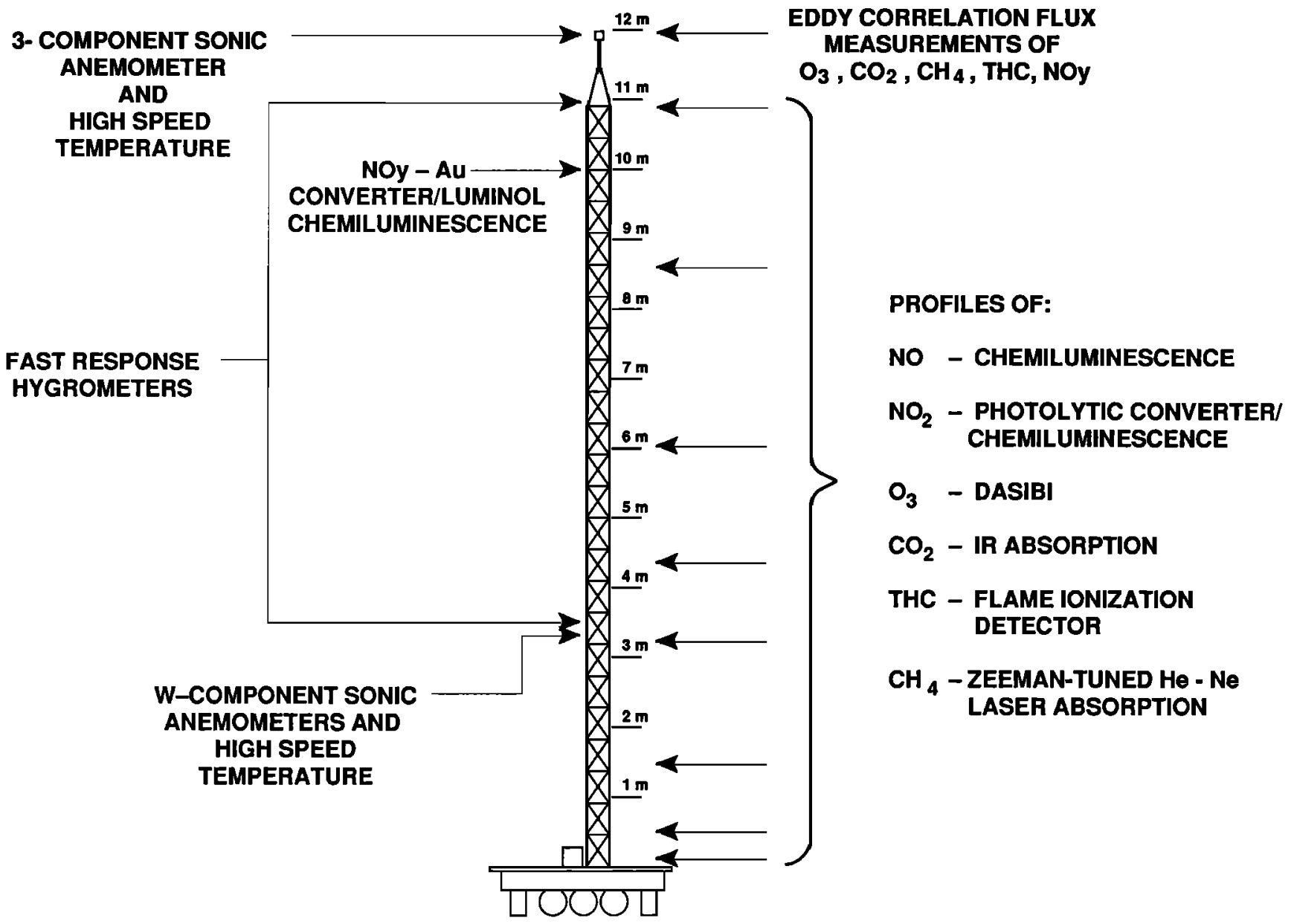

Fig. 6. Ground-based micrometeorological tower used for conducting flux measurements in a tundra environment near Bethel, Alaska.

from sub-Arctic forest fires are sources of reactive nitrogen gases to the sub-Arctic and Arctic troposphere during summer months. The tundra ecosystem is a net sink for atmospheric nitrogen species. A brief synthesis of the ground and airborne nitrogen measurements is presented here as a guide to the detailed results presented in other papers in this issue [Bakwin et al., this issue; Sandholm et al., this issue; Jacob et al., this issue (a); Singh et al., this issue $(a, b)$; Talbot et al., this issue; Wofsy et al., this issue].

Both ground and airborne measurements indicate that the

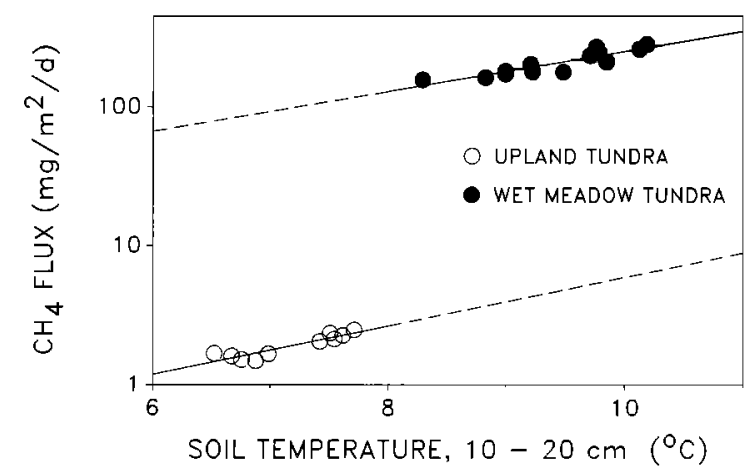

Fig. 7. Fluxes of methane from two ABLE 3A study sites [Bartlett et al., this issue].
sub-Arctic tundra ecosystem is a net sink for atmospheric nitrogen species. Bakwin et al. [this issue] report a nearcontinuous time series of $\mathrm{NO}, \mathrm{NO}_{2}$, and total $\mathrm{NO}_{y}$ measurements at the Lake ABLE ground site for July and August. The fluxes of $\mathrm{NO}_{x}$ and $\mathrm{NO}_{y}$ determined from these data indicate an emission rate for NO from the tundra surface to the atmosphere of $0.17( \pm .10) \times 10^{9}$ molecules $\mathrm{cm}^{-1} \mathrm{~s}^{-1}$. The mean dry deposition of $\mathrm{NO}_{y}$ to the tundra was 2.0 $( \pm 1.0) \times 10^{9}$ molecules $\mathrm{cm}^{-1} \mathrm{~s}^{-1}$. The mean wet deposition rate for $\mathrm{NO}_{3}^{-}$to the Lake ABLE region during the ABLE study period was approximately $3.9 \times 10^{9}$ molecules $\mathrm{cm}^{-1}$ $\mathrm{s}^{-1}$ [Talbot et al., this issue]. Thus, the tundra was a net sink for atmospheric nitrogen species during this summer period.

Enhanced $\mathrm{NO}_{x}$ and $\mathrm{NO}_{y}$ concentrations observed at the Lake ABLE ground site during the study correlated with the long-range transport of emissions from forest fires into the Yukon-Kuskokwim Delta region. Forest fire emissions polluted a significant portion of the tropospheric column during episodes of westerly flow from the areas of active burning which were centered around the Yukon Flats region north of Fairbanks [Wofsy et al., this issue; Shipham et al., this issue; Harriss et al., this issue; Bakwin et al., this issue (a)]. The $\mathrm{NO}_{\boldsymbol{x}}$ levels associated with emissions from forest fires were often greater than 30 pptv, a level which would promote photochemical $\mathrm{O}_{3}$ production [Jacob et al., this issue; Singh et al., this issue (b)]. However, studies of haze 
layers derived from biomass burning indicate a relatively rapid conversion of $\mathrm{NO}_{x}$ to $\mathrm{PAN}$ in the Alaska troposphere, with consequent low $\mathrm{O}_{3}$ enhancements compared to tropical haze layers [Jacob et al., this issue (a); Wofsy et al., this issue].

The vertical distributions of $\mathrm{PAN}, \mathrm{NO}, \mathrm{NO}_{2}, \mathrm{HNO}_{3}$, and $\mathrm{NO}_{y}$ indicate that the primary sources of these gases to the North American sub-Arctic and Arctic troposphere are a combination of stratospheric intrusions, long-range transport of pollutants from mid-latitude sources, and warm season biomass burning in sub-Arctic environments. The concentration of PAN increases with altitude, with highly variable concentrations above $3 \mathrm{~km}$ (e.g., $<50$ to $>700 \mathrm{ppt}$ ). Singh et al. [this issue (a)] attribute the origin of PAN to a group of diverse sources, including injections of mid-latitude pollution during winter-spring "Arctic haze" events, forest fires, and stratospheric intrusions. It is likely that lightning and aircraft are also potentially significant sources of $\mathrm{NO}_{y}$ to this region. The relative stability of PAN in the cold middle and upper Arctic troposphere promotes accumulation and a lifetime determined primarily by the dynamics of downward transport. In the atmospheric mixed layer $(0-3 \mathrm{~km})$, PAN concentrations are typically $0-50 \mathrm{ppt}$. PAN, and an as yet unidentified suite of organic nitrate gases (alkylnitrates and pernitrates?), has the potential to control the summer $\mathrm{NO}_{x}$ availability in the high-latitude troposphere and thus to determine $\mathrm{O}_{3}$ concentrations and distribution [Singh et al., this issue (b); Jacob et al., this issue (a)]. Photochemical modeling indicated that decomposition of PAN alone could account fully for the $\mathrm{NO}_{x}$ concentrations observed at 0 - to $2-\mathrm{km}$ altitude, but for only $20 \%$ of the $\mathrm{NO}_{x}$ at $5-6 \mathrm{~km}$.

\section{Ozone: Distribution and Variability}

The stratosphere was the dominant source of $\mathrm{O}_{3}$ to lower tropospheric altitudes in the ABLE $3 \mathrm{~A}$ study regions. Welldefined intrusions of $\mathrm{O}_{3}$-rich air from the upper troposphere and stratosphere were directly observed with remote sensing to influence $\mathrm{O}_{3}$ concentrations at altitudes of $1 \mathrm{~km}$ and lower [Browell et al., this issue]. The dynamical characteristics of stratosphere/troposphere exchange at high latitudes has been discussed by several authors [e.g., Gidel and Shapiro, 1980; Shapiro, 1980; Shapiro et al., 1987; Raatz et al., 1985]. The concentrations of $\mathrm{NO}_{x}$ in the region studied were sufficiently low that photochemical processes were typically a net sink for tropospheric $\mathrm{O}_{3}$ [Sandholm et al., this issue; Jacob et al., this issue (a)]. The extensive biomass burning in Alaska during summer 1988 had little impact on the observed tropospheric $\mathrm{O}_{3}$ distributions [Gregory et al., this issue; Browell et al., this issue; Jacob et al., this issue (a); Wofsy et al., this issue]. Long-range transport of photochemically derived $\mathrm{O}_{3}$ from the mid-latitudes into the study area was difficult to detect due to the relatively high "background" of $\mathrm{O}_{3}$ derived from upper atmospheric sources.

$J a c o b$ et al. [this issue (b)] combined the aircraft $\mathrm{O}_{3}$ measurements to estimate an average $0-$ to $7-\mathrm{km} \mathrm{O}_{3}$ column of approximately $6 \times 10^{21}$ molecules $\mathrm{m}^{-2}$. Using the deposition flux average measured at the Lake ABLE tower of $-1.1 \times 10^{11}$ molecules $\mathrm{cm}^{-2} \mathrm{~s}^{-1}$ an $\mathrm{O}_{3}$ lifetime of 8 months was calculated. If the time scale for ventilation of air north of $60^{\circ} \mathrm{N}$ is $2-3$ months the Arctic cannot be viewed as an ultimate sink for $\mathrm{O}_{3}$.

If the PAN and organic nitrates which decompose to

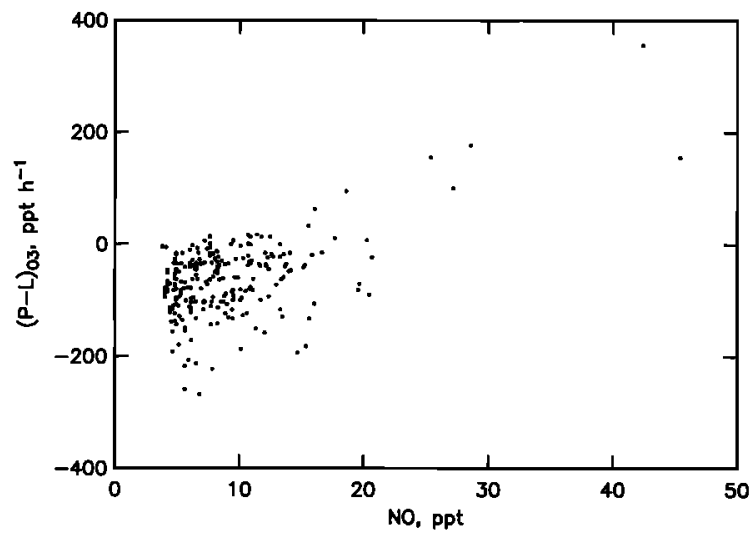

Fig. 8. Photochemical production minus loss rate of $\mathrm{O}_{3},(\mathrm{P}-$ $L_{03}$, as a function of NO concentration. Results are shown for 475 individual points from flights 11-25 where detailed aircraft measurements of atmospheric composition are available. The rates were obtained using a photochemical model [Jacob et al., this issue $(a)$ ]. The ensemble of points covers the altitude range $0.1-6.2 \mathrm{~km}$ and the temporal range 0600-1915 solar time.

produce $\mathrm{NO}_{x}$ in the Arctic are derived, in part at least, from human activities, the lifetime of $\mathrm{O}_{3}$ against photochemical loss may have already increased significantly. Increased $\mathrm{NO}_{x}$ inputs would further reduce the capacity of the Arctic as a region for $\mathrm{O}_{3}$ destruction; in particular, a doubling of $\mathrm{NO}_{x}$ concentrations from present levels would lead to net $\mathrm{O}_{3}$ photochemical production in the Arctic (Figure 8).

\section{Acidic Gases, Aerosols, and Precipitation}

The Arctic and sub-Arctic tropospheric regions studied during ABLE $3 \mathrm{~A}$ were acidic. Formic and acetic acids were the principal acidic gases, the aerosol acidity was due to the presence of "excess" sulfate [Talbot et al., this issue]. The rainwater-free acidity (average $\mathrm{pH}=4.69$ ) in the Bethel area was derived from the carboxylic acids and $\mathrm{H}_{2} \mathrm{SO}_{4}$. Sources of these acids included marine and continental biogenic emissions, forest fires, and to a lesser extent, long-range transport of industrial pollutants.

Nitric acid is a major component of the nitrogen cycle in the boundary layer. Decomposition of PAN and biogenic emissions of $\mathrm{NO}$ are precursors for $\mathrm{HNO}_{3}$ production, biomass burning, and long-range transport of industrial pollutants to the region contribute to episodic increases [Talbot et al., this issue; Bakwin et al., this issue; Jacob et $a l .$, this issue $(a) ;$ Singh et al., this issue $(a, b)]$. The results of photochemical model simulations predict an $\mathrm{HNO}_{3}$ concentration of $50 \mathrm{ppt}$ for the boundary layer [Jacob et al., this issue $(a)]$, the measured mean concentration was $59 \pm 25$ ppt [Talbot et al., this issue]. Nitric acid is the primary component of $\mathrm{NO}_{y}$ dry deposition to the tundra ecosystem [Bakwin et al., this issue].

\section{IMPLICATIONS FOR FUTURE STUdIES}

The results of ABLE 3A confirmed two major hypotheses which generated the study. First, emissions of $\mathrm{CH}_{4}$ from the tundra ecosystem are sensitive to changes in climate variables such as soil moisture and temperature. Enclosure flux measurements, eddy correlation flux measurements from a ground-based tower, and airborne eddy correlation tech- 
niques for $\mathrm{CH}_{4}$ flux measurement, all proved to be robust for use in studying emissions from the tundra landscape. Airborne flux measurements are most useful for surveying large areas to characterize relationships between major ecosystem parameters (e.g., distribution of vegetation type) and $\mathrm{CH}_{4}$ flux. Tower-based eddy correlation and enclosure flux techniques can be best used to quantify specific response functions relating changes in $\mathrm{CH}_{4}$ emissions to changes in soil climate.

Second, concentrations of $\mathrm{NO}_{x}$ are critical to $\mathrm{O}_{3}$ production/destruction processes in the relatively pristine highlatitude regions studied. At present, $\mathrm{O}_{3}$ destruction processes dominate; however, $\mathrm{NO}_{x}$ pollution from mid-latitude sources may have already reduced the capacity of the region to act as an $\mathrm{O}_{3}$ sink [Jacob et al., this issue $\left.(a)\right]$.

These ABLE $3 \mathrm{~A}$ results indicate that atmospheric chemical changes in the Arctic environment may serve as a unique early warning indicator of global change. If northern hemisphere $\mathrm{NO}_{x}$ emissions continue to increase, particularly in the newly industrializing nations (e.g., Korea, China, India), Arctic $\mathrm{O}_{3}$ levels could increase rapidly with significant implications for the northern hemisphere and, perhaps, the global environment. Future studies should emphasize determining the pathways and mechanisms of the transport and fate of $\mathrm{NO}_{y}$ to the Arctic from mid-latitude pollution sources.

Methane flux from tundra environments may be one of the most sensitive, integrative indicators of climate change effects on the Arctic biosphere. A long-term monitoring program of $\mathrm{CH}_{4}$ flux at a network of sites in the tundra ecosystem, in combination with enhanced monitoring of ambient air $\mathrm{CH}_{4}$ trends, could contribute to early detection of climate change effects in the Arctic.

Acknowledgments. The ABLE 3A project acknowledges the assistance and outstanding cooperation provided by both municipal and federal officials in Barrow, Bethel, and Anchorage, Alaska. The U.S. Fish and Wildlife Laboratory in Bethel provided excellent research facilities. The comments of Shaw Liu were very helpful in improving this manuscript. Diana Wright carefully and patiently typed several versions prior to publication.

\section{REFERENCES}

Bakwin, P. S., S. C. Wofsy, S.-M. Fan, and D. R. Fitzjarrald, Measurements of $\mathrm{NO}_{x}$ and $\mathrm{NO}_{y}$ concentrations and fluxes over Arctic tundra, J. Geophys. Res., this issue.

Barrie, L. A., Arctic air pollution: An overview of current knowledge, Atmos. Environ., 20, 643-663, 1986.

Barrie, L. A., and R. M. Hoff, Five years of air chemistry observations in the Canadian Arctic, Atmos. Environ., 19, 1995-2010, 1985.

Barrie, L. A., G. den Hartog, J. Bottenheim, and S. Landsberger, Anthropogenic aerosols and gases in the lower troposphere at Alert, Canada in April 1986, J. Atmos. Chem., 9, 101-127, 1989.

Bartlett, K. B., P. M. Crill, R. L. Sass, R. C. Harriss, and N. B. Dise, Methane emissions from tundra environments in the YukonKuskokwim Delta, Alaska, J. Geophys. Res., this issue.

Billings, W. D., Carbon balance of Alaskan tundra and taiga ecosystems: Past, present, and future, Quat. Sci. Rev., 6, 165$177,1987$.

Bodhaine, B. A., The Barrow aerosol record, 1976-1984, in Arctic Air Pollution, edited by B. Stonehouse, pp. 159-174, Cambridge University Press, New York, 1986.

Bottenheim, J. W., A. J. Gallant, and K. A. Brice, Measurements of $\mathrm{NO}_{y}$ species and $\mathrm{O}_{3}$ at $82^{\circ} \mathrm{N}$ latitude, Geophys. Res. Lett., 11, 113-116, 1986 .

Browell, E. V., C. F. Butler, S. A. Kooi, M. A. Fenn, R. C. Harriss, and G. L. Gregory, Large-scale variability of ozone and aerosols in the summertime Arctic and sub-Arctic troposphere, J. Geophys. Res., this issue.

Chappellaz, J., J. M. Barnola, D. Raynaud, Y. S. Korotkevich, and C. Lorius, Ice-core record of atmospheric methane over the past 160,000 years, Nature, 345, 127-131, 1990.

Crill, P. M., K. B. Bartlett, R. C. Harriss, E. Gorham, E. S. Verry, D. I. Sebacher, L. Madzar, and W. Sanner, Methane flux from Minnesota peatlands, Global Biogeochem. Cycles, 2, 371-384, 1988.

Dickinson, R. E., How will climate change?, in The Greenhouse Effect, Climate Change, and Ecosystems, edited by B. Bolin et al., pp. 206-270, John Wiley, New York, 1986.

Doolittle, J. A., M. F. Gross, and M. Hardisky, A groundpenetrating radar study of active layer thickness in areas of moist sedge and wet sedge tundra near Bethel, Alaska, U.S.A., Arct. Alp. Res., 22, 175-182, 1990.

Fan, S.-M., S. C. Wofsy, P. S. Bakwin, D. J. Jacob, S. M. Anderson, P. L. Kebabian, J. B. McManus, C. E. Kolb, and D. R. Fitzjarrald, Micrometeorological measurements of $\mathrm{CH}_{4}$ and $\mathrm{CO}_{2}$ exchange between the atmosphere and sub-Arctic tundra, $J$. Geophys. Res., this issue.

Ferek, R. J., R. B. Chatfield, and M. O. Andreae, Vertical distribution of dimethylsulphide in the marine atmosphere, Nature, $320,1986$.

Fung, I., J. John, J. Lerner, E. Matthews, M. Prather, L. P. Steele, and P. J. Fraser, Three-dimensional model synthesis of the global methane cycle, J. Geophys. Res., 96, 13,033-13,065, 1991.

Gidel, L. T., and M. A. Shapiro, General circulation model estimates of the net flux of ozone in the lower stratosphere and the implications for the tropospheric ozone budget, J. Geophys. Res., $85,4049-4058,1980$.

Gregory, G. L., et al., Air chemistry over the tropical forest of Guyana, J. Geophys. Res., 91, 8603-8612, 1986.

Gregory, G. L., B. Anderson, L. S. Warren, E. V. Browell, D. Bagwell, and C. Hudgins, Tropospheric ozone and aerosol observations: The Alaskan Arctic, J. Geophys. Res., this issue.

Hameed, S., and R. D. Cess, Impact of a global warming on biospheric sources of methane and its climatic consequences, Tellus, 35B, 1-7, 1983.

Harriss, R. C., et al., The Amazon Boundary Layer Experiment (ABLE 2A): Dry season 1985, J. Geophys. Res., 93, 1351-1360, 1988.

Harriss, R. C., et al., The Amazon Boundary Layer Experiment (ABLE 2B): Wet season 1987, J. Geophys. Res., 95, 16,721$16,736,1990$.

Harriss, R. C., G. W. Sachse, G. F. Hill, L. Wade, K. B. Bartlett, J. E. Collins, P. Steele, and P. Novelli, Carbon monoxide and methane in the North American Arctic and sub-Arctic troposphere: July-August 1988, J. Geophys. Res., this issue.

Hines, M. E., and M. C. Morrison, Emissions of biogenic sulfur gases from Alaskan tundra, J. Geophys. Res., this issue.

Jacob, D. J., et al., Summertime photochemistry in the troposphere at high northern latitudes, J. Geophys. Res., this issue (a).

Jacob, D. J., S.-M. Fan, S. C. Wofsy, P. A. Spiro, P. S. Bakwin, J. Ritter, E. V. Browell, G. L. Gregory, D. R. Fitzjarrald, and K. E. Moore, Deposition of ozone to tundra, J. Geophys. Res., this issue $(b)$.

Khalil, M. A. K., and R. A. Rasmussen, Climate-induced feedbacks for the global cycles of methane and nitrous oxide, Tellus, $41 B$, 554-559, 1989.

Lachenbruch, A. H., and B. V. Marshall, Changing climate: Geothermal evidence from permafrost in the Alaskan Arctic, Science, 234, 689-696, 1986.

Lowenthal, D. H., and K. Rahn, Regional sources of pollution aerosol at Barrow, Alaska during winter 1979-80 as deduced from elemental tracers, Atmos. Environ., 19, 2011-2024, 1985.

McNeal, R. J., J. P. Mugler, Jr., R. C. Harriss, and J. M. Hoell, Jr., NASA Global Tropospheric Experiment, Eos Trans. AGU, 64, 561-562, 1983.

Moore, T. R., and R. Knowles, Methane and carbon dioxide evolution from subarctic fens, Can. J. Soil Sci., 67, 77-81, 1987.

Oltmans, S. J., and W. D. Komhyr, Surface ozone distributions and variations from 1973-1984 measurements at the NOAA Geophysical Monitoring for Climatic Change baseline observatories, $J$. Geophys. Res., 91, 5229-5236, 1986. 
Post, W. M., W. R. Emanuel, P. J. Zinke, and A. G. Strangenberger, Soil carbon pools and world life zones, Nature, 298, 156-159, 1982.

Raatz, W. E., R. C. Schnell, M. A. Shapiro, S. J. Oltmans, and B. A. Bodhaine, Intrusions of stratospheric air into Alaska's troposphere, March 1983, Atmos. Environ., 18, 2153-2158, 1985.

Ramanathan, V., et al., Climate-chemical interactions and effects of changing atmospheric trace gases, Rev. Geophys., 25, 1441-1482, 1987.

Raynaud, D., J. Chappellaz, J. M. Barnola, Y. S. Korotkevich, and C. Lorius, Climatic and $\mathbf{C H}_{4}$ cycle implications of glacialinterglacial $\mathrm{CH}_{4}$ change in the Vostok ice core, Nature, 333, 655-657, 1988.

Sandholm, S. T., et al., Summertime Arctic tropospheric observations related to $\mathrm{N}_{x} \mathrm{O}_{y}$ distributions and partitionings: Arctic Boundary Layer Expedition 3A, J. Geophys. Res., this issue.

Schnell, R. C., Arctic haze and the Arctic gas and aerosol sampling program (AGASP), Geophys. Res. Lett., 11, 361-364, 1984.

Sebacher, D. I., R. C. Harriss, K. B. Bartlett, S. M. Sebacher, and S. S. Grice, Atmospheric methane sources: Alaskan tundra bogs, an alpine fen, and a subarctic boreal marsh, Tellus, 38B, 1-10, 1986.

Shapiro, M. A., Turbulent mixing within tropopause folds as a mechanism for the exchange of chemical constituents between the stratosphere and troposphere, J. Atmos. Sci., 37, 994-1004, 1980.

Shapiro, M. A., T. Hampel, and A. J. Krueger, The Arctic tropopause fold, Mon. Weather Rev., $115,444-454,1987$.

Shipham, M. C., A. S. Bachmeier, D. R. Cahoon, Jr., and E. V. Browell, Meteorological overview of the Arctic Boundary Layer Expedition (ABLE 3A) flight series, J. Geophys. Res., this issue.

Singh, H. B., et al., Atmospheric measurements of peroxyacetyl nitrate and other organic nitrates at high latitudes: Possible sources and sinks, J. Geophys. Res., this issue (a).

Singh, H. B., D. Herlth, D. O'Hara, K. Zahnle, J. D. Bradshaw, S. T. Sandholm, R. Talbot, P. J. Crutzen, and M. Kanakidou, Relationship of peroxyacetyl nitrate to active and total odd nitrogen at northern high latitudes: Influence of reservoir species on $\mathrm{NO}_{x}$ and $\mathrm{O}_{3}, J$. Geophys. Res., this issue (b).

Stonehouse, B. (Ed.), Arctic Air Pollution, 328 pp., Cambridge University Press, New York, 1986.
Talbot, R. W., R. C. Harriss, E. V. Browell, G. L. Gregory, D. I. Sebacher, and S. M. Beck, Distribution and geochemistry of aerosols in the tropical North Atlantic troposphere: Relationship to Saharan dust, J. Geophys. Res., 91, 5173-5182, 1986.

Talbot, R. W., A. S. Vijgen, and R. C. Harriss, Soluble species in the summer Arctic troposphere: Acidic gases, aerosols, and precipitation, J. Geophys. Res., this issue.

Van Cleve, K., and V. Alexander, Nitrogen cycling in tundra and boreal ecosystems, Terrestrial Nitrogen Cycles, Ecol. Bull., 33, 375-404, 1981.

Whalen, S. C., and W. S. Reeburgh, A methane flux time series for tundra environments, Global Biogeochem. Cycles, 2, 399-409, 1988.

Whalen, S. C., and W. S. Reeburgh, Consumption of atmospheric methane by tundra soils, Nature, 346, 160-162, 1990.

Whiting, G. J., D. S. Bartlett, S.-M. Fan, P. S. Bakwin, and S. C. Wofsy, Biosphere/atmosphere $\mathrm{CO}_{2}$ exchange in tundra ecosystems: Community characteristics and relationships with multispectral surface reflectance, J. Geophys. Res., this issue.

Wofsy, S. C., et al., Atmospheric chemistry in the Arctic and sub-Arctic: Influence of natural fires, industrial emissions, and stratospheric inputs, J. Geophys. Res., this issue.

D. S. Bartlett and R. C. Harriss, Institute for the Study of Earth, Oceans and Space, University of New Hampshire, Durham, NH 03824.

R. J. Bendura, J. W. Drewry, J. M. Hoell, Jr., and M. C. Shipham, Atmospheric Sciences Division, NASA Langley Research Center, Hampton, VA 23665.

R. N. Gidge, R. L. Navarro, and V. E. Rabine, NASA Wallops Flight Facility, Wallops Island, VA 23337.

D. J. Jacob and S. C. Wofsy, Harvard University, Cambridge, MA 02138.

R. J. McNeal, Earth Science and Applications Division, National Aeronautics and Space Administration, Washington, DC 20546.

(Received December 10, 1990; revised July 31, 1991; accepted August 12, 1991.) 